\title{
KOMPETENSI DAN PERAN MU'ALLIM DALAM PENDIDIKAN
}

\section{COMPETENCE AND ROLE OF MU'ALLIM IN EDUCATION}

Dody Riyadi H.S.

Sekolah Tinggi Ilmu Tarbiyah (STIT) Ya'mal Tangerang, Perintis, Jl. Raya KPR-BTN Kutabumi, Desa Karet, Kecamatan Sepatan, Kabupaten Tangerang, Banten 15520 email: dryasdryas@yahoo.com

\begin{abstract}
Among the four components of education, mu'allim is the most important components which significantly influencies the other three components i.e student, subject, method. Mu'allim refers to Allah, whereas Adam and Muhammad became the first and the last students correspondingly. The first three chapters revealed to prophet Muhammad contained four competencies of mu'allim. The objective of this research is not only to redefine the concept of mu'allim, but also to describe various competencies and mu'allim's role so as to allow its prophetic profession to be more significant in social institution. This research uses descriptive qualitative method with collecting documented data technique on written sources about mu'allim. Since it refers to Allah and prophet Muhammad, the sacrality of mu'allim concept cannot be interpreted merely as a teacher teaching religious study at school. Mastery of spiritual, intellectual, personal, and social competence makes mu'allim status prophetic, just as prophet Muhammad whose role was not limited only as a patron for his children at home and teacher for students at school, but also as social transformer. Since both teacher and lecturer are called mu'allim, therefore, intellectual competency does not only become mandatory to be mastered by lecturers but also by teachers so as to enable them to develop knowledge through scientific publications.
\end{abstract}

Keywords: Competence; Education; Mu'allim; Role

\begin{abstract}
Abstrak
Di antara empat komponen utama pendidikan, mu'allim merupakan komponen terpenting yang berpengaruh signifikan terhadap tiga komponen lain, yakni murid, materi, metode. Mu'allim merujuk kepada Allah, sedangkan Adam dan Muhammad menjadi murid pertama dan terakhir Allah. Tiga surah pertama yang diwahyukan kepada Nabi Muhammad mengandung empat kompetensi mu'allim. Tujuan penelitian ini tak hanya untuk meredefinisi konsep mu'allim, namun juga untuk mendeskripsikan berbagai kompetensi dan peran mu'allim agar peran profesi profetik itu signifikan di institusi sosial. Penelitian ini menggunakan metode deskriptif kualitatif dengan teknik pengumpulan data dokumentasi terhadap sumber tertulis mengenai mu'allim. Karena merujuk kepada Allah dan Nabi Muhammad, sakralitas konsep mu'allim tak cukup diartikan guru yang mengajarkan ilmu agama di sekolah. Penguasaan atas kompetensi spiritual, intelektual, personal, dan sosial membuat status mu'allim menjadi profetis seperti Nabi Muhammad yang tak hanya berperan sebagai pengasuh anak di keluarga dan pengajar murid di sekolah tetapi juga menjadi pentransformasi masyarakat. Karena baik guru maupun dosen disebut mu'allim, maka kompetensi intelektual, sebagai contoh, tak hanya wajib dikuasai dosen, tetapi juga mesti dimiliki guru agar dapat mengembangkan ilmu lewat publikasi ilmiah.
\end{abstract}

Kata Kunci: Mu'allim; Kompetensi; Pendidikan; Peran 


\section{PENDAHULUAN}

Menurut Quraish Shihab (1996b), Alquran adalah kitab pendidikan. Hampir semua hal yang terkait dengan pendidikan termaktub secara tersurat atau tersirat dalam kitab suci tersebut. Tiga surah pertama, yakni Al-'Alaq, Al-Muddaṡsir, dan Al-Muzzammil yang diwahyukan Allah SWT kepada Nabi Muhammad SAW lewat Jibril dapat dijadikan rujukan sekaligus akses untuk mengungkap berbagai hal terkait dengan pendidikan. Berdasarkan ketiga surah itu, ditemukan empat komponen pendidikan yang disebut $4 \mathrm{M}$ : mu'allim, murid, materi, metode. Quraish Shihab, kendati membicarakan keempat hal itu tetapi tak eksplisit menyebut $4 \mathrm{M}$ komponen pendidikan. Artikel ini merujuk kepada tulisan Quraish Shihab di majalah Ummat. Seorang muslim, apa pun profesinya, berkewajiban meninggikan kalimat Allah (QS. 9:40) dan bertanggung jawab mempraktikkan ilmu yang dikuasainya untuk memobilisasi masyarakat melakukan kebaikan sekaligus mengantisipasi keburukan (QS. 3:104) (Ba-Yunus \& Ahmad, 1996).

Quraish Shihab menyebut murid (muta'allim) sebagai peserta didik. Murid bukan hanya sekelompok siswa yang mendapatkan pengasuhan (tarbiyah), pendidikan (tadīb) dan pengajaran (ta'lìm) di institusi pendidikan. Murid termasuk juga anak atau anggota keluarga yang mempelajari sesuatu di institusi keluarga serta anggota masyarakat yang mendapatkan ilmu pengetahuan dari tiga institusi sosial lainnya, yakni agama, politik, dan ekonomi. Muta'allim tercipta dari tiga unsur terpadu, yaitu jasmani, akal (intelektualitas), jiwa (spiritualitas). Ketiga hal itu tak dapat dipisahkan karena berada dalam satu tubuh. Pendidikan harus mengintegrasikan ketiganya secara serempak dan simultan, bersamaan dan berkelanjutan. Penekanan atau pengabaian pada salah satu atau dua unsur tersebut berakibat pada tidak berfungsinya secara utuh kemanusiaan seseorang serta berdampak pada berkurang bahkan gagalnya seorang individu sebagai makhluk sosial dalam berinteraksi dengan individu-individu lainnya di lembaga-lembaga sosial keluarga, pendidikan, agama, politik, dan ekonomi.
Materi utama dan pertama yang disampaikan mu'allim kepada murid adalah tentang wujud dan keesaan Tuhan yang menekankan non kompromistis atas syirik kepada-Nya. Materi berikutnya dalam rangkaian akidah adalah sifat Tuhan, khususnya Maha mengetahui, yang menanamkan kepada murid perihal kemampuan Allah menyingkap hal sekecil apa pun. Berakhlak kepada kedua orang tua terutama ibu menjadi materi selanjutnya setelah kewajiban esensial murid terhadap keesaan Allah. Mempersekutukan Allah dan mendurhakai kedua orang tua hakikatnya menzalimi diri sendiri. Materi tentang akidah dan akhlak dapat disampaikan mu'allim secara selang-seling agar tidak menjenuhkan murid, selain untuk menginternalisasikan kepada murid mengenai akidah-akhlak yang integral. Ibadah salat menjadi materi berikutnya setelah akidah dan akhlak disusul dengan mengerjakan yang makruf sebelum mengajak orang lain melakukannya. Bersikap lemah lembut dan sopan santun dalam berkomunikasi dengan orang lain adalah materi setelah akidah, akhlak kepada orang tua, dan salat. Kesombongan dan berbagai sikap serta tindakan tercela murid dalam berinteraksi merefleksikan kualitas kompetensi serta keteladanan mu'allim dalam mentransmisikan dan mempraktikkan ilmu pengetahuan.

Terdapat lima jenis metode pendidikan. Pertama, panggilan. Sosiologi pendidikan menyebutnya sosialisasi kasih sayang. Salah satu panggilan terbaik yang diabadikan Alquran adalah "yā bunayya!" (hai anakku! [QS. 31:13]). Itu adalah panggilan mesra Lukman untuk anaknya. Kedua, penalaran, pembuktian, argumen. Metode ini digunakan untuk menstimulasi kognisi murid. Ayat yang terjemahnya familiar untuk membuat murid bernalar dengan baik adalah " $\mathrm{Ya}$ Allah rahmatilah keduanya sebagaimana mereka berdua (merahmati kami dalam) mendidik aku ketika kecil" (QS. 17:24). Ketiga, penahapan dan pembiasaan. Salat, sebagai contoh, tidak serta merta diwajibkan kepada murid lima kali sehari. Tahap pertama pendidikan salat dimulai dengan menanamkan keindahan ciptaan Tuhan yang tersebar di alam raya dan dekat dengan kehidupan murid, seperti sungai, hutan, pantai, gunung. Tahap kedua adalah salat dua kali 
sehari dengan toleransi berbicara. Tahap berikutnya kewajiban melaksanakan salat seperti dilakukan orang dewasa. Keempat, peneladanan. Inilah unsur utama pendidikan: pencontohan lewat tindakan nyata mu'allim yang dilihat murid. Yang diteladani murid adalah tindakan sosial mu'allim sebagai contoh hidup atau model bergerak materi atau pelajaran yang disampaikan lisan.

Kelima, ganjaran dan hukuman. Ganjaran dijanjikan dan diberikan bila keempat metode telah konsisten diaktualisasikan dengan hasil yang terukur jelas. Bila semua metode (panggilan mesra kasih sayang, penalaran atau kemampuan berargumentasi, penahapan dan pembiasaan, peneladanan) telah ditempuh namun belum menampakkan hasil yang signifikan, maka sanksi atau hukuman dapat digunakan. Namun, prinsip penahapan mesti dikedepankan. Islam, tak hanya teoritis tetapi juga praktis, didakwahkan Nabi Muhammad dengan persuasi dan kelemahlembutan, kesabaran dan memaafkan, dalam beragam situasi sosial dan politik (Arnold, 1985). Ta'lìm yang mengandalkan kekasaran dan kekerasan untuk mendisiplinkan anak, murid, atau siapa pun justru mengakibatkan kekacauan jiwa dan pikiran. Tindakan dan ucapan mereka tak didasarkan pada integritas moral kejujuran atau ketulusan, melainkan karena ketakutan pada hukuman yang membentuk karakter malas, penipu, pengkhianat, licik. Yahudi dengan akhlak buruknya seperti pengkhianat dan licik merupakan contoh faktual bangsa yang sepanjang sejarahnya mengalami sekaligus melakukan kekerasan (Ibnu Khaldun, 1986).

Di antara keempat komponen pendidikan itu, mu'allim merupakan komponen utama, didasarkan pada hadis "bu'itstu mu'alliman" (aku diutus sebagai guru) dan "bu'itstu liutammima makārim al-akhlāq" (aku diutus untuk menyempurnakan akhlak) yang menegaskan karakter fundamental mu'allim sekaligus tujuan utama pendidikan. Ketiga komponen lainnya, khususnya murid, tergantung pada kompetensi mu'allim untuk dikembangkan potensi jasmani, akal, dan jiwanya. Tanpa mu'allim tak ada aktivitas taklim atau pengajaran. Tanpa taklim tak ada materi yang secara sistematis disusun dalam kurikulum untuk diajarkan kepada murid. Tanpa mu'allim pula, elaborasi beragam metode pengajaran dan eksplorasi beraneka media pembelajaran untuk mengajarkan materi kepada murid tidak dapat diejawantahkan. Siapa sesungguhnya mu'allim dan kompetensi apa saja yang harus dikuasai mu'allim berdasarkan ketiga surah tersebut agar dapat berperan maksimal tidak hanya di institusi pendidikan tetapi juga di empat institusi sosial lainnya, yakni keluarga, agama, politik, dan ekonomi?.

\section{METODOLOGI}

Permasalahan mu'allim terkait dengan salah satu tema pokok Alquran, yakni tentang manusia, dalam hal ini Adam sebagai individu, yang mengungguli malaikat, disebabkan oleh, selain ruh Tuhan, manusia, menurut Fazlur Rahman (2017), memiliki kapasitas pengetahuan kreatif akibat $t a '$ 'ìm Allah sebagai mu'allim kepada Adam sebagai muta'allim. Penafsiran tematik, menurut Quraish Shihab (1996), tak cukup menjadikan satu atau dua ayat sebagai rujukan. Namun, paling tidak merujuk kepada ayat-ayat pokok mengenai tema yang diteliti, dengan syarat, pertama, mempelajari konteks masing-masing ayat, sejarah, dan latar belakang turunnya ayat, kedua, menemukan pelbagai argumennya tak hanya dari penjelasan Nabi tetapi juga dari hakikat-hakikat ilmiah yang telah mapan, termasuk dari pakar kontemporer dalam bidang Alquran dan pendidikan. Untuk mendapatkan ayat-ayat utama yang relevan dengan mu'allim, penulis menggunakan Al-Mu'jam al-Mufahras li al-Fāzh al-Qur'ān al-Karìm.

Karena mu'allim serta berbagai kompetensi dan perannya merupakan konsep Islam yang bersumber dari Alquran dan hadis, terutama pada tiga surah pertama, maka penelitian tematik tentang keguruan ini sebagai, dalam pandangan Yusuf Qardhawi (1999), upaya dialog dan interaksi muslim dengan Alquran dan sejarah Nabi berdasarkan akal dan hati serta konsentrasi untuk dipikirkan secara akademis lewat proses penelitian induktif-deduktif dalam memaknai ayat dan hadis terkait mu'allim. Abbas Mahmud Al'Aqqad sebagaimana dikutip Quraish Shihab (1995a) menegaskan, layaknya orang-orang Arab pada masa dakwah Rasulullah, umat 
Islam kini berkewajiban memahami Alquran. Namun, penafsiran terhadap tema tertentu dalam Alquran, menurut Quraish Shihab (1995a), tidak disesuaikan dengan teori atau temuan ilmiah baru, melainkan menggunakan pendapat cendekiawan dan ulama serta hasil dan percobaan serta pengalaman ilmuan sebagai sumber berinteraksi dan memahami ayat Alquran.

Sebagai istilah kependidikan Islam, mu'allim merupakan konsep fenomenal religius yang rujukannya adalah sekolah surga ketika Allah menjadi guru bagi Adam. Aktivitas ta'lìm lewat interaksi guru-murid Allah-Adam mengenai mutu pendidikan, kompetensi guru, etika murid, dan status kekhalifahan manusia yang merupakan peristiwa sosioreligius itu diinterpretasikan berdasarkan sumber-sumber tertulis otoritatif guna mengingatkan pemangku dan praktisi pendidikan mengenai signifikansi kompetensi dan peran krusial mu'allim dalam institusi pendidikan dan institusi sosial lain. Karena itu, teknik pengumpulan data yang digunakan adalah dokumentasi terhadap kata-kata tertulis para pakar dari buku dan jurnal.

Penelitian kompetensi serta peran mu'allim dalam pendidikan dianalisis secara deskriptif berdasarkan sumber-sumber kualitatif tertulis, tidak dari data wawancara atau angket. Penelitian deskriptif bertujuan menjelaskan masalah atau obyek tertentu secara terperinci (Suyanto, 2015). Penelitian ihwal mu'allim dan berbagai hal krusial terkait dengannya yang ditemukan selama proses pengumpulan serta analisis data dan akan dijelaskan menggunakan deskriptif kualitatif. Oleh sebab itu, hubungan antar variabel dalam penelitian eksplanatif tak digunakan. Qualitative research mendeskripsikan dan menganalisis fenomena, peristiwa, aktivitas sosial, sikap, kepercayaan, persepsi, pemikiran individual maupun kelompok (Sukmadinata, 2013).

\section{HASIL DAN PEMBAHASAN}

\section{Merekonseptualisasi $\mathbf{M u}$ 'allim dan Murid}

Kamus Besar Bahasa Indonesia (KBBI, 1994)) menulis mu'allim dengan satu huruf 1 , yakni mualim, dengan arti (1) orang ahli agama; guru agama (2) penunjuk jalan.
Mualim juga berarti perwira kapal berijazah pelayaran niaga nautika. Bila semua definisi dari KBBI itu digabungkan, maka mualim adalah pakar agama yang keahlian atau kemumpuniannya dibuktikan dengan ijazah yang memberikan kepadanya otoritas untuk menunjukkan jalan kebenaran kepada murid dan masyarakat. Artikel berjudul "Mualim Tulen Kebanggaan Masyarakat Betawi" tentang ketuntasan belajar kepada guru-guru terkemuka, integritas keulamaan, kemumpunian ilmu, kiprah serta warisan kependidikan ulama Betawi Kiai Haji Abdullah Syafi'i merupakan contoh penggunaan kata mualim sesuai maknanya (Indra \& Ahmad B, 2010).

Sedangkan murid diartikan KBBI (1994) sebagai orang (anak) yang sedang berguru (belajar, bersekolah). KBBI membatasi murid hanya sebagai anak yang belajar secara formal di sekolah kepada guru. Terdapat batasan umur dan tempat bagi murid untuk belajar serta batasan tempat mengajar bagi guru. Belajar diartikan KBBI (1994) sebagai (1) berusaha memperoleh kepandaian atau ilmu; membaca; (2) berlatih; (3) berubah tingkah laku atau tanggapan yang disebabkan pengalaman. Tiga arti belajar itu tidak membatasi murid dengan umur dan tempat belajar hanya di sekolah. Belajar tak cuma demi menguasai ilmu, kepandaian atau keterampilan tertentu, tetapi juga untuk mengubah persepsi dan tingkah laku yang dialami murid di mana saja tanpa batasan tempat dan kepada siapa pun yang dianggap guru lewat beragam aktivitas belajar termasuk membaca. Murid bermakna luas, tak terbatas umur, waktu, dan tempat belajar.

Mu'allim adalah ism fä'il, subyek, pelaku, atau pentransfer ilmu yang telah termaktub secara eksplisit dalam lima ayat wahyu pertama yang disampaikan Jibril kepada Nabi Muhammad saat beliau bertahanus di Gua Hira di Jabal Nur. Yang dimaksud dengan "al-ladzi 'allama bi alqalam” (yang mengajar dengan pena) tentu saja Allah, sebagai mu'allim atau guru, di mana Nabi berstatus sebagai muta'allim. Muhammad adalah nabi sekaligus murid terakhir Allah dalam mata rantai kenabian. Dalam sejarah pendidikan manusia, Adam murid pertama Allah saat ia di surga sebelum diturunkan ke bumi untuk menjadi khalifah 
setelah Allah mengajarkan pelbagai karakteristik benda, "wa'allama Ādam al-asmā kullahā" (Dan Dia ajarkan kepada Adam nama-nama (benda) semuanya [QS. 2:31]).

Kemampuan Adam sebagai murid pertama Allah dalam memahami semua nama benda membuktikan kapasitas berpikir analitis manusia yang membuatnya memiliki kompetensi untuk mengetahui apa pun dan menunjukkan manusia merupakan bayangan atau perwujudan fisik semua Nama dan Sifat Tuhan (Nasr, 2003). Penguasaan Adam atas ilmu pengetahuan mengindikasikan potensi kreatif manusia atas malaikat yang membuatnya pantas mengemban kekhalifahan di bumi secara bermoral sebagai amanah Tuhan yang tak mampu dipikul langit dan bumi (Rahman, 2017). Potensi intelektual Adam dan tak diberikan kepada malaikat dalam mengidentifikasi serta memahami hakikat nama-nama benda juga diturunkan Allah kepada keturunan Adam (Al-Syaibany, 1979). Unsur bidimensional ruh Tuhan dan lumpur, statusnya sebagai wakil Tuhan, pengetahuan yang diajarkan Tuhan, dan kehendak bebas memikul amanah sebagai pengelola alam menjadikan manusia lebih mulia ketimbang malaikat dan semua ciptaan Tuhan (Syari'ati, 1982). Dengan akal sebagai potensi khusus manusia yang mampu mengolah informasi serta ilmu dan wahyu dari Allah, maka lahirlah makhluk beradab dari Adam-Hawa sehingga tidak ada lagi perkawinan campuran antara manusia istimewa tersebut dengan makhluk bumi serupa manusia yang tak beradab (Djamaluddin, 2018).

'Alima-ya'lamu-'ilman yang merupakan akar kata mu'allim serta termaktub di surah AlBaqarah pada konteks Adam dan di surah Al'Alaq pada konteks Muhammad berarti mengetahui sesuatu secara mendalam. Dua ayat QS. 35:27-28 secara eksplisit menegaskan kualifikasi seorang 'ālim, berbagai obyek di alam semesta, termasuk fenomena kehidupan manusia, sebagai sesuatu yang harus diteliti lewat teknik penelitian observasi (Riyadi HS, 2009). Mu'allim atau mualim dalam Indonesia adalah guru yang memiliki pengetahuan mendalam tentang pelbagai hal yang diajarkan kepada murid, sebagaimana Allah kepada Adam. Namun, guru bukan dalam pengertian terbatas di sekolah atau perguruan tinggi dengan sejumlah murid atau mahasiswa yang terbagi dalam kelas atau ruang kuliah, melainkan guru dalam pengertian luas dengan kuantitas murid tak terbatas di masyarakat.

Bukan cuma pengetahuan keagamaan yang mesti dikuasai guru, tetapi juga eksakta, ilmu sosial dan humaniora, termasuk kemampuan mengembangkan, mengajarkan, dan menyebarluaskannya melalui beragam cara dan media. Tanpa pengamalan, ilmu tak dapat disebut demikian. Dalam Islam, konsep ilmu dan praktik atau pengetahuan dan perbuatan yang konstruktif merupakan kesatuan logis yang inheren dengan takut (khasyyah) dan ketakwaan. Sebagai kata benda yang berarti orang yang memiliki sifat pengetahuan, 'álim mempunyai makna gramatikal sebagai pelaku tindakan sesuai atau berdasarkan pengetahuannya (Wan Daud, 1997). Baik ilmu maupun amal terdiri dari huruf 'ain, lam, mim, yang secara dialektis menunjukkan kedua konsep itu berkelindan saling membutuhkan satu sama lain bahwa ilmu harus diamalkan dan amal mesti didasarkan ilmu.

Oleh Abdullah Yusuf Ali (1976), 'allama dalam ayat "wa'allama Ādam al-asmā kullahā" ("And He taught Adam the nature Of all things") diterjemahkan dengan taught yang berarti mengajar. Oleh Munir Ba'albaki (1995), teach diartikan yu'allimu, yudarrisu, dan yulaqqinu. John M Echols dan Hassan Shadily (2003) mengartikan teach (taught) dengan (1) mengajar; (2) mengajarkan. Dengan demikian, ism fä'il atau subyek dari yu'allimu dan teach yang sama-sama berarti mengajar adalah mu'allim, teacher, guru. Dalam sejarah pendidikan Islam, terdapat enam tipe guru: mu'allim, muaddib, mudarris, syaikh, ustāz, imām, belum termasuk guru pribadi dan muayyid atau asisten (guru yunior). Mu'allim ditujukan kepada guru sekolah dasar. Muaddib adalah julukan untuk guru sekolah dasar dan menengah. Arti harfiah muaddib adalah orang yang beradab atau guru adab. Mudarris adalah julukan profesional untuk mu'ìd atau pembantu, sama dengan asisten profesor yang bertugas membantu mahasiswa menjelaskan hal-hal sulit mengenai kuliah yang diberikan profesor. Syaikh, guru besar atau master adalah julukan khusus yang mengilustrasikan 
keunggulan akademis atau teologis. Imām adalah guru agama tertinggi (Nakosteen, 1996).

\section{Kualifikasi dan Relasi Mu'allim-Muta'allim dalam Dua Kitab}

Dua di antara berbagai kitab termasyhur yang menguraikan kriteria ideal mu'allim dan muta'allim adalah, pertama, Tadzkirah alSāmi' wa al-Mutakallim fì Ādāb al-'Ālim wa al-Muta'allim karya Burhanuddin Abu Ishaq Ibrahim ibnu Sa'dullah ibnu Jama'ah alKinani. Buku dengan perspektif ilmu fikih dan hadis yang menguraikan rincian praktis ketimbang aturan umum mengenai transmisi tertulis ilmu pengetahuan yang bermakna penting bagi kesarjanaan muslim itu memiliki akurasi meyakinkan (Rosenthal, 1996). Berbagai topik menarik seperti metode belajar, interaksi guru-murid di kelas, perilaku timbal balik guru-murid dan murid-guru, hingga etiket di asrama sekolah dapat dilihat dari daftar isi buku yang disusun pada tahun 1273 M (Nakosteen, 1996).

Buku tersebut merupakan pedoman bagi guru dan murid mengenai pemuliaan adab atau menjunjung tinggi akhlak dalam menuntut ilmu. Untuk guru, akhlak mulia menjadi kualifikasi utama dalam proses pendidikan. Relasi personal guru-murid dalam Islam tidak sekadar interaksi sosial dalam transfer ilmu tetapi juga interkoneksi jiwa dan spiritualitas guru-murid untuk menanamkan nilai-nilai kebaikan guna membentuk karakter murid melalui keteladanan guru. Sebagai aktivitas spiritual, intelektual, dan sosial yang bernilai ibadah, kesucian hati serta keikhlasan dan kesungguhan niat mendidik menjadi prasyarat rohani bagi guru untuk mengamalkan ilmu sekaligus mentransformasi perilaku murid (Darojat, 2017). Karena kepentingan murid harus diperhatikan agar ilmu dapat ditransmisikan dan dikuasai dengan baik, maka kepada diri sendiri, guru mesti memiliki kritisisme terhadap kondisi tubuhnya, seperti lapar dan haus serta terhadap situasi batinnya, seperti marah dan persoalan emosional lainnya, sedangkan kepada murid, guru dituntut memiliki sensitivitas kualitas pembelajaran, seperti menyesuaikan suara dengan ruangan serta memperhatikan lama dan pendek waktu mengajar untuk menghindari kejenuhan serta minimnya ilmu yang dipahami murid (Syalaby, 1973).

Kedua, Ta'lìm al-Muta'allim oleh Burhanuddin al-Zarnuji yang ditulis pada tahun $1203 \mathrm{M}$ dan merupakan buku paling terkenal tentang pendidikan dengan cakupan luas mulai dari hakikat dan nilai pendidikan, mempersiapkan pelajaran, memperhatikan berbagai hal penyebab ingat dan lupa, hingga memelihara kekuatan rohani dan jasmani sebagai amanah Tuhan (Nakosteen, 1996). Kitab itu mendeskripsikan secara detail etika yang baik bagi murid dan guru. Terkait dengan guru, tempatnya tak hanya di sekolah dengan sejumlah murid yang dididik dalam waktu tertentu dan terbatas tetapi juga dalam kehidupan sosial dengan masyarakat sebagai murid. Keadilan dalam pengambilan keputusan, kasih sayang, dan kelemahlembutan dalam berinteraksi, serta kehati-hatian dalam bertindak, kepada murid maupun tetangga, adalah karakter mulia yang semestinya telah mendarah daging dalam diri guru dan reflektif dalam perilaku sehingga kewibawaannya terpelihara tak tercoreng fitnah apa pun. Kualifikasi sosial itu mutlak ditelisik murid dalam menentukan guru, di samping umur dan senioritas, kualitas intelektual, serta emosionalnya seperti rendah hati dan sabar agar murid mendapatkan kenyamanan menuntut ilmu (Darojat, 2017).

Tentang murid, Az-Zarnuji (2018) menegaskan, penyebab kegagalan mereka tidak dapat mengamalkan dan menyebarluaskan ilmu sebagai faedah menuntut ilmu adalah kekeliruan metode dan syarat yang diabaikan. Berdasarkan kesalahan metode dan syarat menuntut ilmu itulah Az-Zarnuji memberi judul bukunya Ta'lìm al-Muta'allim Tharìq alTa'allum yang membahas hakikat dan keutamaan ilmu terutama tauhid, akhlak dan fikih yang mesti dikuasai secara profesional, niat mencari dan memilih ilmu yang tujuannya tak cuma menghilangkan kebodohan pada diri sendiri dan orang lain tetapi juga untuk melanggengkan eksistensi Islam, menyeleksi ketat guru lalu memberikan hurmah, rasa takut disertai hormat, tak hanya kepada guru tetapi juga kepada keluarganya, mengambil dan mempelajari adab dengan tidak hanya tekun dan cermat dalam meraih ilmu tetapi juga 
menghafal serta mencatatnya dengan tulisan yang mudah dibaca siapa pun, berbagai sikap batin ketika menuntut ilmu seperti wara, tawakal, tobat, takwa, dan ridha, hingga kepada hal-hal terkait dengan rezeki dan umur yang berkorelasi dengan kebiasaan hidup sehari-hari termasuk pola tidur dan selektif terhadap konsumsi makanan.

Di pesantren, merujuk kepada kitab Ta'lìm al-Muta'allim al-Zarnuji, hurmah murid kepada guru merupakan tradisi yang tidak hanya dilakukan murid secara temporer selama menuntut ilmu di pesantren dan selama sang guru hidup tetapi berlangsung seumur hidup murid dan tidak hanya dimanifestasikan kepada guru tetapi juga kepada keluarga terutama anak-anak guru, kendati murid telah menjadi guru ternama. Karena guru diyakini sebagai perantara atau penyalur kemurahan Tuhan, maka memuliakan guru menjamin keberkahan ilmu murid. Namun, itu dilakukan setelah murid menyeleksi calon guru sebelum meyakini sepenuhnya pelbagai aspek kualitas guru untuk kemudian menjadikan dirinya hamba sang guru (Dhofier, 1994). Bersama dengan kitab-kitab bermazhab Syafii, seperti Ihyā Ulūm al-Dīn al-Ghazali, pengaruh Ta'līm al-Muta'allim yang penulisnya bermazhab Hanafi itu sangat kuat sebagai pedoman santri menuntut ilmu di hampir seluruh pesantren, dengan prinsip, kunci sukses menuntut ilmu adalah murid wajib menghormati guru dan kitab-kitab yang diajarkan guru (Mastuhu, 1994).

\section{Kitab Ādāb al-Ālim wa al-Muta'allim} karya KH Hasyim Asy'ari membahas ihwal yang sama dengan dua buku tersebut, tentang urgensi aplikasi adab dalam institusi pendidikan yang menjadi tanggung jawab guru dan merupakan kewajiban murid. Hanya dengan adab pembentukan karakter mulia manusia dan peradaban suatu bangsa dapat dilakukan (Husaini, 2018). Buku itu, menurut KH Hasyim Asy'ari (2016) disusun sebagai bahan kajian dan pedoman tentang persoalan adab yang sangat dibutuhkan murid, selain fungsinya sebagai alarm pribadi atau kode etik personal bagi guru dan buat siapa pun yang menyadari minimnya ilmu yang dimiliki. Manusia yang niat dan praktik keagamaannya tidak beradab, baik pekerjaan hati maupun ragawi, dalam bentuk akhlak perkataan maupun tindakan, sama dengan tidak memiliki syariat, iman, dan tauhid. Di lembaga pendidikan, akhlak menjadi keniscayaan bagi murid dalam proses belajar dan merupakan keharusan bagi guru dalam mengajar.

Ketiga kitab itu menguraikan sosioreligiusitas dan intelektualitas mu'allim, yakni intimitasnya kepada Allah dan kapasitasnya meneladani Rasulullah yang tercermin dalam akhlak personal mu'allim kepada diri sendiri dengan, sebagai misal, memelihara kesucian serta kebersihan diri dan pakaian, secara intelektual kepada ilmu dengan, di antaranya, memperlakukan secara baik buku dan peralatan menulis, dan secara sosial kepada murid dengan mencintai mereka seperti kepada diri atau anak sendiri serta memilih metode pengajaran yang sesuai dengan karakter dan kecerdasan murid. Keikhlasan dan keridhaan Allah di atas segala apa pun yang duniawi seperti popularitas, harta, kekuasaan, kewibawaan. Mu'allim dengan adabnya menjadi peneladan atau perantara akhlak mulia Nabi, selain kepada keluarga sendiri dan murid dalam institusi pendidikan, juga kepada masyarakat dalam institusi agama, politik, ekonomi. Menyadari betapa mulianya ilmu dan status spiritual mu'allim sebagai pengemban misi profetik guna mengangkat derajat umat lewat penyampaian ilmu pengetahuan (transfer of knowledge) dan peneladanan kebaikan (character building), maka mu'allim, dengan penuh kesabaran bersungguh-sungguh belajar sepanjang hayat (long life education) meningkatkan kualitas akademiknya, termasuk di antaranya menulis karya ilmiah yang selain berfungsi sebagai bahan mengajar juga dipublikasikan kepada khalayak (Asy'ari, 2016; Alim, 2013; Darojat, 2017).

\section{Komparasi Tarbiyah-Murabbī, Ta'līm- Mu'allim, Tadīb-Muaddib}

Dalam QS. 2:30-39 itulah, selain Allah sebagai guru dan Adam sebagai murid, berbagai komponen pendidikan dapat ditemukan seperti tujuan, materi, metode, fasilitas, dan lingkungan pendidikan yang digunakan untuk saling melengkapi dengan ketiga surah pertama tersebut. Kualifikasi atau kriteria ideal Allah sebagai guru dan etika Adam sebagai murid pun dapat dijabarkan dari 
QS. 2:30-39. Pendidikan dalam makna pengajaran (ta'limm) dalam QS. 2:30-39 dinamakan sekolah surga. Tujuan pendidikannya untuk menjadikan manusia sebagai khalifah. Materi pendidikannya terdiri dari apa pun yang dibutuhkan murid untuk menjalankan fungsinya sebagai hamba sekaligus khalifah-Nya. Metode pendidikannya berupa tanya jawab, diskusi, dan berbagai kompetisi untuk mengukur hasil pembelajaran. Fasilitas pendidikannya terdiri dari apa pun yang diperlukan murid. Kriteria ideal guru adalah menguasai ilmu yang dibutuhkan murid, memahami mental atau kejiwaan murid, bijaksana sekaligus penyayang dan pemaaf, visioner atas tindakannya. Etika murid adalah menaati perintah guru, tidak menyombongkan apa pun, meminta maaf bila melakukan kesalahan, tidak menyalahgunakan ilmu. Lingkungan pendidikannya terdiri dari malaikat yang tekun beribadah, iblis yang menyombongkan status sosial dengan menolak kebenaran sekaligus memalingkan manusia dari perintah Tuhan, dan manusia berilmu pengetahuan seperti Adam.

Lingkungan pendidikan harus steril dari siapa dan apa pun yang merusak atau mengganggu proses pembelajaran seperti iblis terhadap Adam yang membuat Adam terusir dari surga. Bila di tempat paling baik, seperti sekolah surga itu, terdapat provokator atau perusak seperti iblis, apalagi di lembagalembaga pendidikan di dunia yang pelakunya bisa siapa saja, termasuk dosen di perguruan tinggi keagamaan Islam dengan perilaku syaitaniah, di antaranya, mengoleksi gelar akademik S-1, S-2 dan S-3 secara mudah, memperjualbelikan skripsi, tesis dan disertasi, memanipulasi berkas akademik atau memplagiasi karya ilmiah untuk kepangkatan atau beban dan laporan kerja dosen untuk sertifikasi dosen, menikmati, membiarkan, atau mengorupsi berbagai finansial mahasiswa dan secara berjamaah merisak dosen yang mengungkap korupsi, menjiplak borang akreditasi dan menyogok asesor, membuka kelas jauh dengan perkuliahan yang dipadatkan dan diampu dosen yang kualitas intelektual dan integritas moralnya meragukan, tak pernah menulis satu pun karya ilmiah selama berstatus dosen tetapi tanpa malu menuntut honor mengajar dan diberikan tugas membimbing serta menguji skripsi. Karena potensi biadabnya yang musykil diperbaiki, iblis-iblis akademik itu mestinya dikeluarkan dari lembaga pendidikan seperti Allah mengusir iblis dari sekolah surga, karena dengan beragam metode, makhluk terkutuk itu merusak mentalitas Adam sebagai muta'allim, siswa atau mahasiswa.

Dalam sejarah kenabian, lewat kata 'allama, peran Allah sebagai guru tak hanya kepada Adam dan Muhammad tetapi juga kepada Sulaiman yang kepadanya Allah mengajarkan pengertian bunyi burung (QS. 27:16). Menurut Zakiah Daradjat et al (2012), kata 'allama, pada konteks Adam dan Sulaiman sekadar memberitahu atau menyampaikan pengetahuan dan tidak bermakna pembinaan karakter atau kepribadian, pimpinan, pemeliharaan dan lainnya seperti terkandung dalam addaba atau rabba. Sangat minim terjadi pembinaan kepribadian Sulaiman dan Adam melalui ta'līm lewat burung dan nama benda. Ketiga konsep pendidikan itu, ta'lim, tarbiyah dan tadīb, harus dikomparasikan, karena tak cuma berbeda arti melainkan juga tidak sama konteks kenabiannya.

Tarbiyah dengan kata kerja rabba yang lazim diartikan pendidikan paling tidak merujuk kepada, pertama, QS. 17:24 yang berarti mengasuh, kedua, QS. 26:18 yang juga berarti mengasuh. Rabbun yang berarti Tuhan dan merupakan kata benda dari rabba tak hanya berarti mencipta tetapi juga mendidik, mengasuh, memelihara (Daradjat et al, 2012), sifat yang seharusnya dimiliki orang tua dan diberikan sepenuh hati kepada anak sehingga disebabkan tarbiyah itulah, anak memohon kepada Tuhan untuk merahmati atau menyayangi ibu-ayah kandungnya. Karena itu pula, kendati Firaun menyatakan telah mengasuh Musa sejak bayi hingga berumur 18 tahun, faktanya Firaun berdusta. Disebabkan keyakinan Musa akan menghancurkan kekuasaannya, Firaun selalu mencari kesempatan untuk membunuh Musa dengan berbagai cara, tetapi gagal, lantaran keselamatan Musa dijaga sepenuhnya oleh istri Firaun. Yang dominan menjadi murabbi atau pengasuh Musa adalah ibu kandungnya di kediamannya sendiri dan sesekali dibawa ke 
istana Firaun untuk dipertemukan dengan Asiyah istri Firaun (As Sayyid, 2015). Andai kata Firaun terlibat dalam proses tarbiyah atas Musa seperti tersimpul dalam kata nurabbika, tetapi secara simplistis, tarbiyah itu sebatas membesarkan tanpa penanaman pengetahuan (Al-Attas, 1996).

Tadīb tidak merujuk kepada Alquran tetapi pada hadis addaban̄ rabbī faahsana tadībī ("Tuhan telah mendidikku, maka Ia menyempurnakan pendidikanku"). Hadis itu mengungkap pendidikan dalam arti sebenarnya sebagaimana diperoleh Nabi yang tak hanya dari Tuhan melainkan juga dari orang-orang terbaik sepanjang hidupnya, mulai dari, pertama, Aminah di Mekah, ibu kandung yang mengasuh Nabi serta menanamkan modal sosial kekeluargaan mengenai pentingnya menjalin dan mempertahankan kekerabatan. Kedua, Halimah Sadiyah di gurun pasir, ibu susuan yang tak cuma memberikan ASI, namun juga mengasuh, merawat serta memperkuat jasmani Nabi dengan makanan halal serta baik dan udara segar untuk pernapasan, di samping melatih ketajaman penglihatan dan kewaspadaan, serta membentuk jiwa atau karakter jujur, tulus, bebas, setia kawan, rajin, berani, fasih dan puitis berbahasa. Ketiga, Abdul Muttalib di Mekah, kakek yang menurunkan karakter kedermawanan, keberanian, dan kebijaksanaan memimpin. Keempat, Abu Thalib, paman yang mengajarkan kesederhanaan serta pengorbanan dan membentuk kemandirian dan kepercayaan diri. Kelima, Khadijah, istri yang memberikan keyakinan spiritual, perlindungan emosional, pengorbanan finansial (Lings, 2016).

Bila Aminah dan Halimah Sadiyah bertanggung jawab terhadap golden age dan dasar-dasar character building Nabi, maka Abdul Muttalib, Abu Thalib, dan Khadijah berperan signifikan memperkaya dan mengokohkan character building beliau. Kelima orang dengan karakter baik itulah yang secara emosional, spiritual, dan sosial menjadi muaddib Nabi sejak ia dilahirkan hingga wafatnya Khadijah. Pada konteks inilah, tarbiyah, ta'lìm, dan tadīb dapat dikomparasikan, berdasarkan konteks kenabian, tetapi merupakan rangkaian kesatuan urutan. Tarbiyah seperti dialami Musa terkait dengan pengasuhan orang tua di institusi keluarga dengan batasan umur sejak bayi hingga remaja. Ta'lìm seperti dialami Adam, Sulaiman, dan Muhammad terkait dengan pengajaran guru di institusi pendidikan pada usia remaja atau dewasa pasca tarbiyah. Tadīb seperti dialami Nabi Muhammad terkait dengan pembentukan fisik dan psikis oleh banyak pendidik di berbagai institusi sosial, tak hanya keluarga dan pendidikan tetapi juga agama, politik dan ekonomi, sejak bayi hingga dewasa. Saat tadīb berlangsung empat puluh tahun yang terkandung di dalamnya tarbiyah itulah, di Gua Hira, Nabi Muhammad, lewat Jibril, mulai mendapatkan ta'lìm dari Allah.

Tadīb itulah yang membuat Al-Attas (1996) menegaskannya sebagai istilah pendidikan Islam sebenarnya, bukan tarbiyah, yang kendati terdapat dalam Alquran, tetapi secara semantik, mengacu kepada apa pun yang tumbuh secara fisik dan material, tidak hanya anak manusia tetapi juga tanaman, hewan, mineral, serta spesies lainnya. Hanya tadīb, tegas Al-Attas (1996), satu-satunya istilah pendidikan untuk manusia yang artinya berpadanan dengan ta'lim yang merujuk kepada keteladanan Tuhan mengajarkan para nabi. Adab sebagai akar kata, inti, proses, dan tujuan $\operatorname{tad} \bar{i} b$ yang dilakukan berdasarkan ilmu dan amal membentuk kedisiplinan tubuh, kematangan jiwa, dan kekuatan ruh yang menjadikan manusia mampu mengenali dan mengakui hierarki ilmu dan tingkatan wujud lalu menempatkan potensi dan kompetensi jasmaniah, intelektualitas, dan rohaniahnya secara adil sehingga mampu berpartisipasi aktif secara sukarela dalam pelbagai situasi sosial (Al-Attas, 1996). Adab, menurut AlAttas, kini telah lenyap dari umat Islam dan menjadi ancaman internal serius yang membuat pencarian, pengajaran, pengamalan, dan pengembangan ilmu menjadi tak bermakna. Pelbagai masalah yang dialami umat Islam tidak diakibatkan krisis politik, konflik agama, atau ekonomi, melainkan oleh loss of adab: hilangnya kedisiplinan badan, pemikiran, dan jiwa. Adablah yang diyakini Al-Attas mampu menuntaskan berbagai persoalan yang membelit umat Islam (Husaini, 2017). 
Kendati berbeda kata, teks, konteks dan interpretasi, namun bila dikembalikan kepada Alquran, para pakar dari beragam disiplin ilmu berada pada titik temu bahwa Allah sumber keteladanan implementasi ketiga konsep itu. Ta'lìm mengenai nama-nama benda sebagaimana diberikan Allah kepada Adam merupakan pusat perhatian Islam, karena ta'lìm tak hanya membuat Adam dari lempung menjadi pemilik nama-nama tetapi mentransformasi dirinya lebih mulia ketimbang malaikat dari cahaya dan iblis dari api kemudian menempatkannya di bumi sebagai khalifah (Syari'ati, 1982). Adab sebagai inti dan proses tadīb bertujuan menanamkan kebaikan material dan spiritual pada manusia yang secara individual di alam ruh sebelum memperoleh bentuk jasmaniah telah mengenal, mengakui, dan menegaskan Allah sebagai Tuhan $(a l-r a b b)$ melalui kapasitas ilmu rohaniah (Al-Attas, 1996). Sifat pendidikan, berdasarkan ayat pertama wahyu pertama, adalah rabbāniy, dan oleh sebab itu, pelaku pendidikan, seperti diidentifikasi QS 3:79 disebut rabbāniy, dengan karakteristik, di antaranya, mengajarkan (mu'allim) kitab Allah, baik tertulis, yakni Alquran, maupun tidak tertulis, yakni alam raya, serta mempelajarinya (mudarris) secara berkesinambungan (Shihab, 1995a).

\section{Kompetensi Mu'allim dalam Surah Al-} 'Alaq, Al-Muddaṡsiir, Al-Muzzammil

Dalam bahasa Inggris, kompetensi (competence), kata benda, berarti kecakapan, kemampuan; (2) wewenang, sementara kompeten (competent), kata sifat, berarti cakap, mampu (Echols \& Shadily, 2003). KBBI (1994) mengartikan kompetensi sebagai kewenangan (kekuasaan) untuk menentukan (memutuskan sesuatu). Sebagai kata sifat, kompeten, diartikan KBBI sebagai (1) cakap (mengetahui); (2) berwenang; berkuasa (memutuskan, menentukan) sesuatu. Peraturan Pemerintah Republik Indonesia Nomor 74 Tahun 2008 tentang Guru mendefinisikan kompetensi sebagai seperangkat pengetahuan, keterampilan, dan perilaku yang harus dimiliki, dihayati, dikuasai, dan diaktualisasikan guru dalam melaksanakan tugas keprofesionalan. Kompetensi yang dimaksud meliputi pedagogis, kepribadian, sosial, dan profesional yang diperoleh melalui pendidikan profesi. Keempat kompetensi itu holistik.

Kompetensi spiritual, yang oleh KBBI (1994) diartikan sebagai berhubungan dengan atau bersifat kejiwaan (rohani, batin) dan spirit yang merupakan kata benda diartikan KBBI sebagai (1) semangat (2) jiwa; sukma; roh, adalah kecakapan utama dan pertama mu'allim. Kendati ayat-ayat dalam ketiga surah itu menggunakan konsep, frase, atau kalimat berbeda tetapi substansinya sama, yakni Tuhan $(r a b b)$. Di antara konsep, frase, atau kalimat spiritual tersebut di antaranya adalah bi ismi rabbik (QS. 96:1), wa rabbuk al-akram (QS. 96:3), wa rabbak fakabbir (QS. 74:3), wa udzkur ism rabbik (QS. 73:8), hudā (QS. 96:11), wa usjud wa iqtarib (QS. 96:19), 'abdan idzā shallā (96:10), wa tabattal (QS. 73:8), qum al-laila illā qalīlā (QS. 73:2), annaka taqūm adnā min tsulutsay al-lail aw nishfah (QS. 73:20), taqwā (QS. 74:56; QS. 96:12) Allāh yarā (QS. 96:14), wa rattil alqur'ān tartīlà (QS. 73:4), fa iqraū ma tayassara min al-qur'ān (QS. 73:20). Konsep, frase, dan kalimat yang sifatnya spiritual itu jauh lebih banyak ketimbang konsep, frase, dan kalimat yang terkait dengan kompetensi intelektual, personal, dan sosial mu'allim. Itu menegaskan, spiritualitas, kepekatan, dan kelekatan batin mu'allim dengan Tuhan menjadi fundamen jiwa bagi tanggung jawab konkret keilmuan, karakter, dan interaksi sosial mu'allim dengan sesama mu'allim dan murid, kepada orang tua dan masyarakat, serta terhadap pemerintah.

Menurut Quraish Shihab (1995b), karena beratnya tanggung jawab mu'allim, hanya kepada Allah keluh-kesah, permohonan, dan pertolongan disampaikan. Dalam bahasa "kids zaman now", anak zaman sekarang atau generasi masa kini, curahan hati mu'allim hanyalah kepada Allah dan bukan kepada siapa pun, karena Allah-lah pemberi amanah pelbagai tanggung jawab keguruan sebagaimana Dia mengamanahkan tugas kerasulan kepada Nabi Muhammad. Mu'allim, berdasarkan hadis "al-'ulamō waratsah alanbiy $\vec{a}$ " (ulama adalah pewaris para nabi), berkomitmen memelihara sekaligus mengamalkan Alquran, hadis serta akhlak 
mulia warisan Nabi dan para nabi sebelum beliau.

Salat fardu lima kali sehari belum memadai untuk menyucikan niat, menguatkan mental, dan memudahkan guru menyampaikan ilmu, memecahkan berbagai persoalan pengajaran, menghadapi keragaman karakter murid dan orang tua. Salat sunah terutama tahajud di saat sebagian besar manusia tertidur pulas adalah waktu yang efektif untuk berkomunikasi secara personal dengan Tuhan. Hanya di atas sajadah dan bukan berselimut hangat di atas kasur empuk yang membuat jiwa, akal, dan fisik mu'allim teruji, terbukti, terpuji. Intimitas spiritual yang konsisten dikonstruksi dengan berendah diri dan tulus ikhlas dalam memuliakan Tuhan lewat salat fardu dan tahajud membuat mu'allim selalu yakin akan petunjuk (hudā) Tuhan sehingga membuatnya percaya diri, namun tetap rendah hati dan takut (taqwā), karena selain Tuhan Maha Pencipta dan Maha Pemelihara, tak ada satu pun makhluk-Nya yang agung. Pengagulan diri mu'allim, betapa pun mulia profesi dan hebat kemampuannya, mendiskualifikasi kompetensi lainnya sekaligus menjatuhkan derajat insaniahnya. Kesombongan, meskipun sekecil atom, berdampak buruk, tidak hanya kepada mu'allim sebagai pribadi tetapi juga terhadap murid dan mu'allim lainnya serta bagi masyarakat.

Kedua, kompetensi intelektual lewat kata Iqra/membaca, meneliti (QS. 96:1), alqalam/menulis (QS. 96:4), 'allama/mengajarkan (QS. 96:5) yang disingkat batula: baca, tulis, ajarkan (Riyadi HS, 2008). Lima ayat surah Al-'Alaq diwahyukan kepada Nabi ketika beliau sedang bertahanus, beribadah dan bertafakur, di Gua Hira pada 17 Ramadan. Tahanus atau penyendirian spiritual untuk beribadah sekaligus untuk menjauhkan diri dari pelbagai kontaminasi sosial dilakukan Nabi setiap Ramadan, tak hanya ketika wahyu pertama itu tiga kali dibacakan Jibril (Lings, 2016). Muhammad, sama dengan Ibrahim, memahami fenomena sosial dan hakikat penciptaan alam lewat metode perenungan mendalam, pengamatan berulang, berakhir dengan keyakinan ketauhidan.
Karena keummian Muhammad, tidak dapat atau tak pernah membaca dan menulis sebuah kitab pun, maka perintah Jibril untuk membaca merujuk kepada berbagai obyek yang ditahanuskannya. Pertama, realitas keagamaan penuhanan berhala dan penyimpangan keagamaan lainnya. Kedua, fenomena sosial dominasi elite agama, ekonomi dan politik Quraisy, subordinasi perempuan, perbudakan, peperangan antarsuku, mabuk-mabukan, perjudian. Ketiga, penciptaan alam semesta. Keempat, wahyu pertama dan wahyu berikutnya yang kemudian terkumpul pada satu kitab tertulis. Wahyu pertama menjadi dasar teologis bagi perubahan besar metodologi ilmu pengetahuan serta perubahan mendasar bagi konsepsi ketuhanan dan kesederajatan kemanusiaan.

Iqra berasal dari akar kata qara'a yang berarti menghimpun dan tak hanya berarti bacalah tetapi multi arti: sampaikanlah, telaahlah, dalamilah, telitilah, ketahuilah ciri sesuatu, baik teks tertulis yang bersumber dari Tuhan berupa kitab suci serta apa pun karya manusia maupun teks alam raya serta pelbagai aspek kehidupan manusia (Shihab, 1995). Begitu luas kandungan makna iqra karena begitu universalnya ciptaan dan kekuasaan Tuhan yang harus dibaca. Iqra yang seakar kata dengan Alquran yang berarti bacaan sempurna mesti dilakukan secara sempurna. Alquran, selain sebagai sarana mu'allim untuk berkomunikasi dengan Allah juga menjadi referensi utama mu'allim mendapatkan jawaban atas pelbagai persoalan kependidikan dan keguruan serta persoalan lain. Iqra termaktub tiga kali, dua kali pada QS. 96:1 dan 3 dalam konteks membaca dengan spirit ketuhanan dan satu kali pada QS. 17:14 dalam konteks membaca buku amal pribadi. Qalam selain terdapat pada QS. 96:4 tentang fungsi kalam sebagai sarana transmisi pengetahuan juga terdapat pada QS. 68:1 tentang fungsi kalam sebagai instrumen menulis. 'Allama selain termaktub pada QS. 96:4 dan 5 tentang pengajaran Tuhan melalui kalam untuk memberdayakan manusia juga pada QS. 2:31 tentang pengajaran Tuhan kepada Adam tentang seluruh nama benda dan pada QS. 55:2 tentang Kemahapemurahan Tuhan yang mengajarkan Alquran. 
Kata 'allama pada konteks Adam dan Muhammad selain sebagai fakta kontinuitas tauhid dalam rangkaian kenabian juga sebagai sistematika ilmu. Kepada Adam manusia dan nabi pertama, Tuhan mengajarkan secara langsung nama-nama seluruh benda tanpa perantara qalam. Sedangkan kepada Muhammad rasul terakhir, Tuhan menegaskan urgensi qalam untuk menulis, mengembangkan, dan mengabadikan ilmu pengetahuan demi memberdayakan manusia, " allama alinsān mā lam ya'lam" (Dia Mengajarkan manusia apa yang tak diketahuinya [QS. 96:5]). Iqra dalam Al'-Alaq diulang dua kali sebagai perintah bahwa membaca, baik fenomena alam dan sosial maupun Kitab Suci dan teks tertulis lainnya, tidak cukup dilakukan satu kali tetapi berulang kali, demi kecermatan, ketepatan, dan obyektivitas. Pengulangan itu juga menunjukkan bahwa obyek, informasi, atau data yang dibaca tidak satu tetapi beragam agar pengetahuan yang ditulis serta diajarkan untuk mentransformasi, memberdayakan, atau mencerdaskan manusia valid secara ilmiah (keilmuan), insaniah (kemanusiaan), ilahiah (ketuhanan).

Penyelidikan ilmiah atau pemahaman yang hanya fokus pada satu obyek di alam raya hanya melahirkan kesia-siaan, bahkan pemberhalaan manusia terhadap obyek tertentu yang menafikan Tuhan dalam hierarki benda dan ilmu. Aktivitas ilmiah dalam Islam bukan hanya berorientasi pada pengembangan ilmu tetapi juga sebagai eksplorasi dan internalisasi sifat-sifat Tuhan untuk meningkatkan jiwa dan akal (Stanton, 1994). Rangkaian membaca, menulis, dan mengajarkan ilmu pengetahuan merupakan metodologi religius ilmu pengetahuan. Hasil membaca, meneliti, mengamati, dan aktivitas ilmu lainnya mesti ditulis supaya dapat dibaca dan diverifikasi, dengan tujuan bukan hanya, pertama, untuk diajarkan kepada manusia melainkan juga, kedua, untuk pengembangan ilmu, sekaligus, ketiga, proses tanpa batas pemberdayaan pelbagai potensi manusia sebagai makhluk, hamba, dan khalifah Tuhan Yang Maha Pemurah.

Tanpa membaca, tak mungkin ada sesuatu yang ditulis. Tanpa literasi, bacaan atau tulisan, mustahil terwujud aktivitas pengajaran, proses belajar-mengajar, deduksiinduksi, teori-observasi, tesis-sintesis-antitesis, ontologi-epistemologi-aksiologi. Tanpa aktivitas iqra-qalam-'allama, bukan hanya mustahil berlangsung pengembangan ilmu, namun juga musykil terwujud pemahaman mendalam atas hakikat penciptaan alam semesta, asal kejadian dan proses reproduksi manusia serta tujuan eksistensi manusia di bumi sebagai abdi sekaligus sebagai khalifahNya serta pertanggungjawaban amalnya kelak. Tanpa metodologi iqra terhadap Kitab Suci, kehidupan manusia, dan alam, mustahil Islam menjadi rahmat universal bagi siapa dan apa pun di alam raya. Kata 'alam dalam "wa $m \bar{a}$ arsalnāka illā rahmah li al- 'ālamīn" (Dan Kami tidak mengutus engkau (Muhammad) melainkan untuk (menjadi) rahmat bagi seluruh alam [QS. 21:107]) seakar dengan kata 'allama yang integral dengan iqra dan qalam.

Motivasi keilmuan iqra tak hanya karena Allah (bi ism rabbik) tetapi juga bahwa proses tanpa henti serta hasil membaca mesti diorientasikan untuk mewujudkan manfaat bagi manusia, selain untuk terus-menerus meningkatkan keyakinan religius (wa rabbuk al-akram) bahwa Dialah yang telah menciptakan alam beserta isinya, menjadikan manusia sebagai hamba sekaligus khalifahNya, mengirimkan nabi dan rasul-Nya untuk menyampaikan risalah-Nya, serta menjadikan Islam dan Alquran sebagai agama dan Kitab Suci-Nya yang paripurna. Bila dikaitkan dengan perintah membaca, menelaah, meneliti, menghimpun, dan semua arti yang terkandung dalam iqra, maka bi ism Rabbika yang merupakan syarat membaca tak hanya berarti membaca dengan ikhlas tetapi juga selektif memilih bacaan yang tidak kontradiktif dengan "nama Allah" untuk memperoleh ilmu, pemahaman dan wawasan baru, sedangkan manfaat membaca yang terkandung dalam wa rabbuka Al-Akram bermakna bahwa puncak dari segala yang terpuji dapat dianugerahkan Tuhan kepada siapa pun yang melakukan aktivitas membaca (Shihab, 1995).

Perintah membaca-menulis-mengajarkan (iqra-qalam- 'allama) dengan spirit ketuhanan (bi ism rabbik) dan Kemahapemurahan-Nya (wa rabbuk al-akram) menegaskan identitas dan aktivitas ilmu pengetahuan Islam, pertama, 
tidak sekular, material dan partikular melainkan spiritual dan universal (rahmah li al'älaminn); kedua, tidak dikotomis agama, eksakta, sosial dan humaniora tetapi integratif sekaligus multiperspektif; ketiga, tidak obyektif-eksploitatif namun konstruktifregeneratif, keempat, tidak culas tetapi etis. Pada poin keempat itulah, yakni etis atau menjunjung tinggi etika akademik, mu'allim terlaknat melakukan aksi antiintelektual seperti plagiarisme, apa pun modus, motif serta sanksinya, yang dampaknya tak cuma merusak diri sendiri dan institusi pendidikan, tetapi juga menghancurkan mentalitas generasi dan peradaban bangsa (Riyadi HS, 2017). "Bi ismi rabbik" dan "wa rabbuk al-akram" menegaskan intelektualitas, tradisi pemikiran, atau produktivitas ilmiah dalam Islam inheren dengan spiritualitas yang membuat mu'allim meyakini pelanggaran etika akademik sama dengan menegasikan identitas atau spirit ketuhanan dari aktivitas ilmiah. Religiusitas dan intelektualitas atau kebertuhanan dan berilmu pengetahuan telah diintegrasikan Islam sejak awal kehadirannya, mendahului apa yang kini disebut etika akademik, kaidah atau norma ilmiah, hak atas kekayaan intelektual.

Penelitian (iqra) dan publikasi ilmiah ('allama bi al-qalam), pengajaran serta pemberdayaan masyarakat ('allama al-insān mā lam ya'lam) dalam Al-'Alaq, yang dalam konteks pendidikan tinggi disebut Tri Dharma Perguruan Tinggi tidak hanya menjadi tanggung jawab dosen di pendidikan tinggi tetapi juga menjadi tugas guru di sekolah. Sebab, baik dosen maupun guru, dalam Alquran dan hadis, sama-sama disebut mu'allim dan kedua profesi itu merupakan amanah profetik yang mesti diinternalisasi dan diaktualisasikan secara profesional. Sabda Nabi "bu'itstu mu'alliman" dapat dimaknai "aku diutus sebagai dosen atau guru profesional dengan seperangkat kompetensi." Penelitian atau publikasi karya ilmiah, tak dapat dibebankan hanya kepada mu'allim di PT. Semua mu'allim di setiap jenjang pendidikan, sejak PAUD, TK, SD hingga PT, bertanggung jawab secara spiritual untuk mengamalkan ilmu tak hanya secara sosial melalui lisan dan keteladanan yang berskala terbatas, tetapi juga dituntut menyebarluaskan ilmu secara intelektual lewat tulisan yang berdaya jangkau lintas tempat dan waktu.

Kompetensi ketiga dan keempat mu'allim adalah personal dan sosial, di antaranya $w a$ isbir 'alā mā yaqūlūn wa uhjurhum hajran jamīla (QS. 73:10), wa lirabbik fa isbir (QS. 74:7), wa tsiyābak fathahhir (QS. 74:4), wa al-rujz fa uhjur (QS. 74:5) wa lā tamnun tastaktsir (QS. 74: 6). Kemampuan mengendalikan diri atau konsistensi menjaga ketenangan jiwa yang direfleksikan mu'allim lewat interaksi sosial di berbagai institusi dalam bentuk stabilitas emosi tatkala menghadapi masalah atau situasi sesulit apa pun dimotivasi dan diorientasikan semata untuk dan kepada Allah, seperti tersurat dalam QS. 74:7. Hanya dengan perilaku dan ungkapan baik atau meninggalkan secara etis yang dipesankan Alquran kepada mu'allim untuk merespons tindakan dan ucapan buruk murid serta orang tua di sekolah dan anggota masyarakat dalam kehidupan sosial. Lapang dada hanya dimiliki mu'allim yang afeksi ketuhanannya terbukti terpuji dan menjadi teladan konkret bagi siapa pun yang berinteraksi dengannya. Persoalan yang dihadapi mu'allim, sebagai orang tua di institusi keluarga dan sebagai guru di institusi pendidikan maupun sebagai warga negara diselesaikan berdasarkan spiritualitas kerendahan hati dan kedekatan jiwanya kepada Allah (QS. 96:19) dan dilandaskan pada intelektualitasnya atas Alquran dan ilmu (QS. 74:55-56).

Penampilan, sebagaimana tersurat dalam QS. 74:4, tak bisa diabaikan mu'allim. Pakaian yang melekat di tubuh mu'allim merupakan cermin spiritualitas sekaligus refleksi akhlaknya di institusi keluarga, pendidikan, dan institusi sosial lain. Perintah "wa tsiyābak fathahhir" (dan bersihkanlah pakaianmu) tak hanya terkait dengan kesucian pakaian yang harus selalu terjaga dari berbagai najis yang merusak relasi spiritual mu'allim dengan Allah lewat ritualitas salat. Kesucian pakaian dapat diperluas maknanya secara sosial dengan penampilan yang menarik asalkan tetap etis, sopan, apik atau rapi (baik, teratur, bersih), dan harum. "Libās al-taqwā" dalam QS. 07:26 selain dapat diartikan sebagai pakaian yang terjaga aspek materialnya dari najis dan 
terpelihara unsur sosialnya dari aurat juga dapat dimaknai sebagai pakaian spiritual yang memperindah jasmani mu'allim dengan akhlak mulia atau budi pekerti yang baik.

Dalam soal materi, mu'allim dituntut untuk berhati-hati mencari atau menerimanya. Aplikasi takwa (QS. 74:56; 96:12) dan keyakinan total mu'allim bahwa Allah senantiasa memperhatikan sangat teliti (QS. 96:14) apa pun yang dilakukan atau didapatnya membuat mu'allim hanya menerima rezeki yang memang menjadi hak atas kinerja kompetensinya. "Walā tamnun tastaktsir" (dan janganlah engkau (Muhammad) memberi (dengan maksud) memperoleh (balasan) yang lebih banyak [QS. 74: 6]) bermakna bahwa mu'allim dan orientasi materi merupakan dua hal yang bertentangan. Secara singkat dapat dikatakan bahwa bila berharap saja tidak boleh apalagi menuntut lebih. Bila berharap saja dianggap tidak etis dan menuntut lebih dinilai tak bermoral, apalagi korupsi, baik finansial maupun intelektual, dengan berbagai jenis atau beragam bentuknya itu.

Bukan hanya dalam soal pendapatan yang diperhatikan secara kritis oleh mu'allim, tetapi dalam hal apa pun yang dapat merusak integritas profesi profetik mu'allim. "Wa alrujz fa uhjur" (dan tinggalkanlah segala (perbuatan) yang keji) menuntut mu'allim untuk berhati-hati menjaga tindak-tanduk, perilaku, karakter, akhlaknya. Allah pasti melihat apa pun perbuatan mu'allim dan apa pun yang dilakukan mu'allim pasti diperhatikan siapa pun, tak hanya oleh murid, namun juga oleh mu'allim-mu'allim lain serta oleh siapa pun dalam kehidupan mu'allim. Allah mencatat perbuatan mu'allim, murid mengingat keteladanan mu'allim, masyarakat mengawasi ketat perilaku mu'allim. Kognisi, afeksi, dan psikomotorik mu'allim mencerminkan akidah, akhlak, ibadah, dan hatinya yang mempengaruhi kebertuhanan, budi pekerti, pengetahuan, dan interaksi sosial murid-muridnya.

\section{Meneladani Nabi Muhammad: Peran Sosiologis Mu'allim dalam Institusi Pendidikan dan Institusi Sosial Lain}

Sebagai profesi profetik, kualitas sempurna kompetensi Nabi Muhammad sebagai mu'allim untuk memperbaiki akhlak menjadi referensi sublim bagi siapa pun yang berprofesi sebagai pendidik, yakni guru dan dosen. Penguasaan seutuhnya mu'allim atas keempat kompetensi itu membuat mu'allim memiliki empat peran sosiologis seperti Rasulullah: ke kanan, bersama Khadijah, sukses mengasuh (tarbiyah) dan mendidik (tadīb) anak-anak dan siapa pun yang berada dalam pengasuhan di institusi keluarga (Lings, 2016), ke kiri, berhasil mengajar ( $t a$ 'lìm) murid di institusi pendidikan seperti di rumah AlArqam ibnu Abil Arqam ketika di Makkah (Sjalaby, 1973), ke bawah, mampu mentransformasi kehidupan sosial di institusi agama lewat Masjid Nabawi ketika di Madinah (Haekal, 1984), ke atas, secara strategis melakukan persuasi, nasihat, amar-makruf dan nahi-munkar terhadap elite zalim di institusi politik dan ekonomi selama periode Makkah dan Madinah hingga akhirnya sukses merevolusi tradisi jahiliah saling serang dan perang antarsuku karena dendam dengan perdamaian sebagai sesama muslim (Armstrong, 2014).

Jauh sebelum kerasulannya, Nabi telah menjadi aktivis organisasi sosial Hilf $\mathrm{Al}$ Fudhūl yang fokus pada perlindungan penduduk kota Makkah dan pendatang tertindas (Sardar \& Malik, 1997). Tawaran duniawi Quraisy kepada Nabi berupa kekayaan berlimpah dan kekuasaan tertinggi hingga tekanan mental sekeras apa pun termasuk hoaks paling kasar yang menuduh beliau sebagai laki-laki yang kerasukan, peramal, penyair, penyihir, bahkan pemalsu ajaran agama tidak dapat menggoyahkan kemanusiaan beliau sebagai insan kamil yang memandang kehidupan dunia (duny $\bar{a})$ dengan perspektif agama $(d \bar{l} n)$ berorientasi akhirat sehingga statusnya sebagai pemimpin jamaah di masjid, komandan pasukan di medan perang, dan negarawan pemimpin sidang pelbagai masalah sosial mampu beliau perankan secara gemilang (Ahmed, 1997).

Kesuksesan Nabi sebagai mu'allim dapat dilihat pada begitu banyak murid beliau yang menguasai beragam ilmu, mengembangkan serta mengaplikasikannya dalam berbagai bidang kehidupan. Di antara mereka adalah Umar bin Khattab yang selain dikenal sebagai 
ahli hukum juga masyhur sebagai teknokrat yang memerintah dengan tegas dan adil. Sementara putra Umar, Abdullah, memiliki keistimewaan ilmiah sebagai pengumpul hadis yang dilakukan penuh ketelitian (Yunus, 1992). Keberhasilan Rasulullah sebagai mu'allim disebabkan kepribadian beliau sebagai pendidik yang, di antaranya, sangat memotivasi aktivitas menuntut ilmu sekaligus mengidentifikasi dan meningkatkan potensi berbeda setiap murid dengan implementasi berbagai metode mendidik, tak hanya melalui keteladanan atau tindakan nyata, namun juga lewat nasihat, tahapan, kiasan, dialog, hingga dengan kabar gembira dan ancaman (AlThahhan, 2017). Keteladanan dan akhlak mulia berdasarkan Alquran yang dipraktikkan secara konkret dan konsisten sebelum meminta orang lain melakukan sesuatu merupakan metode paling krusial di antara pelbagai metode pengajaran Rasulullah yang sangat variatif. Metode itulah yang selain berpengaruh mendalam di jiwa karena signifikan menanamkan karakter juga efektif memudahkan pemahaman serta melekatkan ilmu ke dalam pikiran murid (Abu Ghuddah, 2018).

Dengan kompetensi intelektual seperti diperintahkan Allah lewat surah Al-'Alaq, pengamalan ilmu oleh mu'allim tak hanya lewat lisan di ruang kelas atau kuliah tetapi juga melalui berbagai publikasi ilmiah yang berimplikasi positif terhadap pendapatan mu'allim, sehingga membuat mu'allim, dalam soal finansial, tak berharap lebih dari pengajaran. Dengan intelektualitas pula, kritikan mu'allim terhadap pemerintah dilakukan secara beradab, tidak melulu lewat unjuk rasa yang mengganggu aktivitas rutin publik. Dengan kompetensi personal belas kasih dan penyayang serta lemah lembut seperti Nabi, mu'allim memiliki hati sedalam samudera yang tidak akan dangkal, pikiran seluas cakrawala yang tidak pernah sempit, dan emosi sekokoh batu karang yang tidak dapat rapuh untuk menampung keluh-kesah serta menangani pelbagai masalah murid dan beragam karakter orang tua mereka. Kompetensi sosial yang rendah hati, ramah, pemaaf, dan dialogis membuat mu'allim terlibat dalam gerakan, organisasi, atau aktivisme sosial untuk menuntaskan berbagai masalah kependidikan dan kemasyarakatan secara intelektual dan penuh integritas dengan bantuan dan bimbingan Tuhan.

Bila keempat kompetensi itu tak dikuasai dengan baik oleh mu'allim, maka ia relatif gagal mendidik keluarga dan mengajar murid, tak banyak berkiprah di masyarakat, takut memberikan peringatan kepada penguasa, pemerintah, atau pemimpin korup. Tanpa empat kompetensi yang teruji, terbukti, dan terpuji membuat mu'allim, guru dan dosen, tidak berbeda dengan buruh di pabrik yang meskipun memproduksi barang bermerek, tetapi tanpa jiwa dan akal. Tanpa empat kompetensi, eksistensi mu'allim di institusi pendidikan tak ubahnya parasit yang menggerogoti secara perlahan namun pasti hingga akhirnya menumbangkan pohon yang ditumpanginya. Rutinitas harian mu'allim sejenis ini berbicara tak tentu arah di ruang kelas atau kuliah sambil berharap cemas menanti honor mengajar setiap awal bulan. Hidupnya berfungsi minimalis di dua institusi sosial keluarga dan pendidikan. Spiritualitas dan intelektualitasnya meragukan, personalitas dan sosialnya mencurigakan.

\section{PENUTUP}

Mu'allim tak cukup diartikan ahli agama yang mengajarkan ilmu kepada sejumlah murid di institusi pendidikan. Berasaskan tiga surah pertama, mu'allim memiliki seperangkat kompetensi yang jauh berbeda dengan, misalnya, empat kompetensi guru pada Undang-Undang Republik Indonesia Nomor 14 Tahun 2005 tentang Guru dan Dosen. Mu'allim pertama bagi umat manusia dan para nabi adalah Allah. Nabi Muhammad menjadi mu'allim tak hanya bagi umat Islam tetapi buat seluruh manusia. Alquran telah menetapkan kompetensi ideal mu'allim dengan tegas dan Rasulullah sudah meneladankan mu'allim ideal secara jelas melalui kepribadian dan berbagai metode pendidikan yang menghasilkan begitu banyak murid yang kompeten dalam bidang ilmu berbeda.

Kompetensi spiritual, intelektual, personal, dan sosial dibebankan kepada dosen maupun guru. Kendati masing-masing profesi itu mengajarkan ilmu di jenjang pendidikan berbeda, tetapi Alquran melabeli keduanya 
sebagai mu'allim dan menuntut keduanya menguasai keempat kompetensi itu dengan tanggung jawab implementasi yang sama. Penguasaan mu'allim atas keempat kompetensi membuat pengajaran ilmu kepada murid serta pengamalan ilmu kepada masyarakat dan terhadap pemerintah menjadi mudah. Pelbagai persoalan yang dihadapi mu'allim di institusi sosial diselesaikan dengan, pertama, keyakinan spiritual, kedua, kekuatan intelektual, ketiga, kualitas personal, keempat, integritas sosial. Jika keempat kompetensi itu tak dikuasai mu'allim, maka peran guru dan dosen sebagai pengasuh, pendidik, dan pengajar keluarga, murid, dan masyarakat serta sebagai pemberi nasihat dan peringatan terhadap pemerintah menjadi tidak maksimal, gagal, dan menjadi benalu yang menumpang hidup di lembaga pendidikan yang membebani bahkan dapat merusak masyarakat.

\section{DAFTAR PUSTAKA}

Abu Ghuddah, Abdul Fattah (2018) Muhammad Sang Guru; Menyibak Rahasia Cara Mengajar Rasulullah. Jakarta: Akses.

Ahmed, Akbar S (1997) Living Islam: Tamasya Budaya Menyusuri Samarkand hingga Stornoway. Bandung: Mizan.

Ali, Abdullah Yusuf (1976) An Interpretation of The Holy Qur'an with Full Arabic Text. Lahore: Sh. Muhammad Ashraf Kashmiri Bazar.

Alim, Ahmad (2013) "Ilmu dan Adab dalam Islam", dalam Adian Husaini et al. Filsafat Ilmu; Perspektif Barat dan Islam. Jakarta, Gema Insani.

Armstrong, Karen (2014) Sejarah Islam: Telaah Ringkas-Komprehensif Perkembangan Islam Sepanjang Zaman. Bandung: Mizan.

Al-Attas, Syed Muhammad Al-Naquib (1996) Konsep Pendidikan dalam Islam: Suatu Rangka Pikir Pembinaan Filsafat Pendidikan Islam. Bandung: Mizan.

Arnold, Thomas W (1985) Sejarah Da'wah Islam. Jakarta: Widjaya.

Asy'ari, KH Hasyim (2016) Pendidikan Akhlak untuk Pengajar dan Pelajar
(Ādāb al-Ālim wa al-Muta'allim). Tebuireng: Pustaka Tebuireng.

Ba'albaki, Munir (1995) Al-Mawrid A Modern English-Arabic Dictionary. BeirutLebanon: Dar El-Ilm Lil-Malayen.

al-Baqy, Muhammad Fuad 'Abd (1987) AlMu'jam al-Mufahras li al-Fāzh alQur'ān al-Karìm. Beirut: Dar al-Fikr.

Ba-Yunus, Ilyas dan Farid Ahmad (1996) Sosiologi Islam dan Masyarakat Kontemporer. Bandung: Mizan.

Daradjat, Zakiah et al (2012) Ilmu Pendidikan Islam. Jakarta: Bumi Aksara.

Darojat, Much Hasan (2017) "Kode Etik Guru dan Murid Menurut Ibn Jamā'ah dan AlZarnuji, Islamia, XI(2), h. 107-117.

Dhofier, Zamakhsyari (1994) Tradisi Pesantren Studi tentang Pandangan Hidup Kyai. Jakarta: LP3ES.

Djamaluddin, T. (2018) Semesta pun Berthawaf: Astronomi untuk Memahami Al-Quran. Mizan: Bandung.

Echols, John M dan Hassan Shadily (2003) Kamus Inggris-Indonesia. Jakarta: PT Gramedia Pustaka Utama.

Haekal, Muhammad Husain (1984) Sejarah Hidup Muhammad. Jakarta: Tintamas.

Husaini, Adian (2017) "Konsep Adab dalam Falsafah Pendidikan al-Attas", Islamia, XI(2), h. 72-82.

Husaini, Adian (2018) "Jadilah Santri-Santri Pejuang!”, Republika, p. 18

Ibnu Khaldun (1986) Muqaddimah. Jakarta: Pustaka.

Indra, Hasbi dan Ahmad B (2010) "Mualim Tulen Kebanggaan Masyarakat Betawi", Media Indonesia, p. 8.

Kementerian Agama RI Direktorat Jenderal Bimbingan Masyarakat Islam Direktorat Urusan Agama Islam dan Pembinaan Syariah (2012) Al-Qur'an dan Terjemahnya. Jakarta: Kementerian Agama RI.

Lings, Martin (2016) Muhammad: Kisah Hidup Nabi Berdasarkan Sumber Klasik. Jakarta: Serambi. 
Mastuhu (1994) Dinamika Sistem Pendidikan Pesantren: Suatu Kajian Tentang Unsur dan Nilai Sistem Pendidikan Pesantren. Jakarta: INIS.

Nakosteen, Mehdi (1996) Kontribusi Islam atas Dunia Intelektual Barat: Deskripsi Analisis Abad Keemasan Islam. Surabaya: Risalah Gusti.

Nasr, Seyyed Hossein (2003) The Heart of Islam: Pesan-pesan Universal Islam untuk Kemanusiaan. Bandung: Mizan.

Qardhawi, Yusuf (1999) Berinteraksi dengan Al-Qur'an. Jakarta: Gema Insani Press.

Rahman, Fazlur (2017) Tema-tema Pokok AlQur'an. Bandung: Mizan.

Riyadi HS, Dody (2008) "Metodologi Iqra", Satelit News, p. VI.

Riyadi HS, Dody (2009) "Meredefinisi Ulama", Republika, p. 6.

Riyadi HS, Dody (2017) "Plagiarisme dan Korupsi Ilmu Pengetahuan”, Kordinat, XVI(2), h. 271-292.

Rosenthal, Franz (1996) Etika Kesarjanaan Muslim dari Al-Farabi hingga Ibnu Khaldun. Bandung: Mizan.

Sardar, Ziauddin dan Zafar Abbas Malik (1997) Mengenal Islam for Beginners. Bandung: Mizan.

As Sayyid, Kamal (2015) The Greatest Stories of Al Quran. Jakarta: Zahra.

Shihab, M. Quraish (1995) "Membumikan" Al-Quran: Fungsi dan Peran Wahyu dalam Kehidupan Masyarakat. Bandung: Mizan.

Shihab, M. Quraish (1996a) Wawasan AlQuran: Tafsir Maudhu'i atas Pelbagai Persoalan Umat. Bandung: Mizan.

Shihab, Quraish (1996b) "Pendidikan AlQur'an”. Ummat, p. 74-75.

Sjalaby, Ahmad (1973) Sedjarah Pendidikan Islam. Djakarta: Bulan Bintang.
Stanton, Charles Michael (1994) Pendidikan Tinggi dalam Islam: Sejarah dan Peranannya dalam Kemajuan Ilmu Pengetahuan. Jakarta: Logos Publishing House.

Sukmadinata, Nana Syaodih (2013) Metode Penelitian Pendidikan. Bandung: Remaja Rosdakarya.

Suyanto, Bagong (2015) "Menetapkan Fokus dan Merumuskan Masalah yang Layak Diteliti”, dalam Bagong Suyanto dan Sutinah (ed.): Metode Penelitian Sosial Berbagai Alternatif Pendekatan. Jakarta: Prenada.

al-Syaibany, Omar Mohammad Al-Toumy (1979) Falsafah Pendidikan Islam. Jakarta: Bulan Bintang.

Syari'ati, Ali (1982) Tentang Sosiologi Islam. Yogyakarta: Ananda.

al-Thahhan, Mustafa Muhammad (2017) Gurunya Umat Manusia; Belajar Metode Nabi Mengajar. Jakarta: Qalam.

Tim Penyusun Kamus Pusat Pembinaan dan Pengembangan Bahasa (1994) Kamus Besar Bahasa Indonesia. Edisi Kedua. Jakarta: Balai Pustaka.

Wan Daud, Wan Mohd. Nor (1997) Konsep Pengetahuan dalam Islam, Bandung: Mizan.

Yunus, Mahmud (1992) Sejarah Pendidikan Islam dari Zaman Nabi SAW, Khalifahkhalifah Rasyidin, Bani Umaiyah dan Abbasiyah sampai Zaman Mamluks dan Usmaniyah Turki. Jakarta: Hidakarya Agung.

Az-Zarnuji, Burhanul Islam (2018) Talìm alMuta'allim: Wasiat Imam Az-Zarnuji Terkait Adab, Akhlak, dan Metode Menuntut Ilmu. Solo: Pustaka Arafah.

Indonesia (2008) Peraturan Pemerintah Nomor 74 tentang Guru. Indonesia

Indonesia (2005) Undang-Undang Nomor 14 tentang Guru dan Dosen. Indonesia. 